\title{
Function of $\beta$-Cells and Insulin Resistance in Long-Standing Type 2 Diabetes Mellitus*
}

\author{
Damira Kadić1, \\ Davorka Dautbegović- \\ Stevanović ${ }^{2}$, \\ Sabaheta Hasić 3
}

${ }^{1}$ Department of Laboratory Diagnostics and ${ }^{2}$ Department of Internal Diseases, Cantonal Hospital Zenica, Zenica, Bosnia \& Hezegovina 3Department of Medical Biochemistry, Faculty of Medicine, University of Sarajevo, Sarajevo, Bosnia \& Herzegovina

\author{
Correspondence \\ Dr Damira Kadić \\ Department of Laboratory Diagnostics, \\ Cantonal Hospital Zenica \\ Crkvice 67, 720oo Zenica \\ Bosnia \& Herzegovina \\ Phone: +38732405133 \\ Fax: +38732226576 \\ e-mail:damira.kadic@gmail.com
}

Submitted: April 22, 2013

Accepted: September 15, 2013
Type 2 diabetes mellitus (T2DM) is the most common form of diabetes and defects of both insulin action and insulin secretion are usually present by the time of diagnosis. It is progressive disorder of glucose metabolism with decreased $\beta$-cells function and insulin resistance as the dominant factors in its genesis. ${ }^{1}$ The environmental factors, weight gain and physical inactivity exacerbate metabolic abnormalities present in this disease. ${ }^{2}$ Every patient with T2DM secretes less insulin than necessary for his/her level of in-

\footnotetext{
" This paper was presented at the First congress on diabetes mellitus, Banja Luka, Republic of Srpska, Bosnia \& Herzegovina, March, 2013. (1 st Diabetology congress of Republic of Srpska, 21-24.03.2013.)
}

(Scr Med 2013;44:79-82) sulin sensitivity, and many of them have some degree of insulin resistance. The mix of insulin deficiency and insulin resistance is different for each patient and, in any patient, it may vary during the course of the disease. ${ }^{3}$ Multiple causative factors such as genetic predisposition, insulin resistance, increased insulin secretory demand, glucotoxicity, lipotoxicity, impaired incretin release/action, amylin accumulation and decreased $\beta$-cell mass are implicated in pancreatic b-cells impairment. ${ }^{2}$

Insulin resistance, in pharmacological terms, can be defined as a state in which the normal amounts of insulin produce a subnormal biological response. ${ }^{4}$ It connotes resistance to the effects of insulin on glucose uptake, me- 
tabolism or storage. Insulin resistance is manifested by the decreased insulin-stimulated glucose uptake in adipocytes and skeletal muscles and impaired suppression of hepatic glucose output. ${ }^{5}$ The main causes of the insulin resistance are genetic predisposition, obesity and physical inactivity. ${ }^{6}$ The large amount of abdominal (visceral) fat, found in obese people, is a source of bioactive mediators that directly contribute to insulin resistance and also affect lipid profiles, blood pressure and vascular inflammation. ${ }^{7-9}$

The fact that T2DM patients have different combinations of $\beta$-cells impairment and insulin resistance is well-known, but we have investigated the characteristics of these disorders in a long-standing, poorly controlled T2DM patients treated only by peroral antidiabetics before hospitalization in the Cantonal Hospital Zenica because of the insulin therapy introduction. The assessment of $\beta$-cells function and insulin resistance in a long-standing T2DM patients, as well as the assessment of HbA1c and obesity allows setting of an appropriate glycemic target for T2DM patients.

The aim of our study was to examine the degree of $\beta$-cells function and the presence of insulin resistance in patients with a long-standing type 2 diabetes.

\section{Materials And Methods}

Study subjects. The retrospective study was carried out at the Cantonal Hospital Zenica. The data from medical records of 30 patients of both sexes (12 males, 18 females) with the mean age of 59 years $(\mathrm{SD}=7.88)$ were analyzed. The study included the patients with a long-standing T2DM (disease duration more than 5 years) with the mean duration of the disease of 10 years $(\mathrm{SD}=5.36)$, treated with peroral antidiabetics. The patients were hospitalized from August 2010 to October 2011 because of the insulin therapy introduction. The body mass index (BMI), an estimate of overall adiposity, was calculated as the weight in kilograms divided by the height in meters squared. The mean value of BMI was $31 \mathrm{~kg} / \mathrm{m}^{2}(\mathrm{SD}=4.74)$.

Laboratory data. After an overnight fast, the blood samples were drawn for the measurement of fasting blood glucose (FBG), insulin and glycated hemoglobin (HbA1c) concentrations. The measurements were performed at the Department of Laboratory Diagnostics, Cantonal Hospital Zenica by the standard laboratory methods. Specifically, glucose concentrations were measured by enzymatic colorimetric assay on Hitachi 912 (Roche, Basel, Switzerland), insulin by chemiluminescentmicroparticle immunoassay on Architect (Abbot, North Chicago, IL, USA) and HbA1c by turbidimetric immunoassay for glycated hemoglobin/ modification of the alkaline hematin reaction for total hemoglobin on Dimension (Siemens, Munich, Germany). The percentages of functional $\beta$-cells in pancreas (HOMA$\% B$ ), insulin sensitivity (HOMA-\%S) and insulin resistance (HOMA-IR) were calculated using a Homeostatic Model Assessment (HOMA) calculator v2.2. Original HOMA 1 model (first described in 1985. by Matthews et al.) is a structural mathematical model which allows values for insulin sensitivity (which is reciprocal of insulin resistance) and $\beta$-cells function, expressed as a percentage of normal, to be obtained if fasting plasma glucose and insulin concentrations are known..$^{10}$ HOMA 2, currently solved computer model, accounts the differences between hepatic and peripheral insulin secretion or decreases in hepatic glucose production for plasma glucose concentratins above $10 \mathrm{mmol} / \mathrm{L}$, or renal glucose losses. The updated version (1996) of HOMA model incorporates an estimate of proinsulin secretion into the model and allows the use of total or specific insulin assays. ${ }^{11}$

Statistical analysis. The obtained data were analyzed by statistical software SPSS 19(SPSS Inc, Chicago, IL, USA). The results of descriptive statistics were expressed as the mean and standard deviation (SD) or median with the range (25-75 percentile) depending on the data distribution.

\section{Results}

The results of descriptive statistics are presented in tables 1. and 2. The mean FBG value was out of the reference range $(3.3-6.1 \mathrm{mmol} / \mathrm{L})$. The mean HbA1c value was also out of the reference range (4.8-6.0 \%), as expected.

Table 1. The Demographic, anthropometric and glycemic control parameters in 30 type 2 diabetic patients

\begin{tabular}{lllllll}
\hline & \multicolumn{7}{c}{ Statistical parameters } \\
\cline { 2 - 7 } & Mean & SD & Min & Max & Med & Range \\
\hline Age (years) & 59 & 7.88 & 46 & 77 & 57 & $53.0-62.5$ \\
\hline Disease duration (years) & 10 & 5.36 & 5 & 23 & 10 & $5.0-15.0$ \\
\hline BMI (kg/m²) & 31 & 4.74 & 21 & 38 & 32 & $26.8-34.3$ \\
\hline HbA1c (\%) & 10.0 & 1.52 & 7.1 & 13.2 & 10.1 & $8.7-11.0$ \\
\hline FBG (mmol/L) & 12.4 & 4.15 & 5.5 & 20.4 & 11.4 & $9.4-16.5$ \\
\hline
\end{tabular}

Abbrevations: BMI-body mass index; HbA ${ }_{1}$-glycated hemoglobin; FBG-fasting blood glucose; SD-standard deviation; Min-minimum value in the group;Max- maximum value in the group; Med-median value; range-25-75 percentile. 
Table 2. The insulin level and characteristics of Homeostatic Model Assessment in 30 type 2 diabetic patients

\begin{tabular}{lllllll}
\hline & \multicolumn{5}{c}{ Statistical parameters } \\
\cline { 2 - 7 } & Mean & SD & Min & Max & Med & Range \\
\hline Insulin $(\mu \mathrm{mol} / \mathrm{L})$ & 12.8 & 6.11 & 2.6 & 24.9 & 12.0 & $7.7-18.1$ \\
\hline HOMA-\%B (\%) & 31 & 18.99 & 3.7 & 85.5 & 27 & $16.9-41.9$ \\
\hline HOMA-\%S(\%) & 59 & 36.74 & 2.4 & 142.9 & 49 & $32.2-82.4$ \\
\hline HOMA-IR (1) & 2.4 & 1.56 & 0.7 & 8.1 & 2.0 & $1.2-3.1$ \\
\hline
\end{tabular}

Abbrevations: HOMA-\%B-percentage of functional $\beta$-cells; HOMA-\%S-percentage of insulin sensitivity; HOMA-IR-insulin resistance; $S D$-standard deviation;Min-minimum value in the group;Max-maximum value in the group; Med-median value; range-25-75 percentile.

The mean blood insulin value was within the reference range $(3-17 \mathrm{mmol} / \mathrm{L})$. The mean value of HOMA-\%B was highly reduced. The median value of HOMA-\%S was reduced and according to that the median value of HOMA-IR was increased moderately.

HOMA-IR values were elevated (HOMA-IR $>1$ ) in majority of the patients (26 patients, $87 \%$ ). Variety of combinations of insulin deficiency and insulin resistance were present.

\section{Discussion}

We examined the presence and the degree of $\beta$-cells disfunction and insulin resistance in the long-standing T2DM patients. The obtained results revealed the normal insulin level in relative terms. But, in absolute terms, such a level was insufficient to maintain normoglycemia in T2DM patients.

Insulin secretion and action govern glucose homeostasis through two feedback loops. A rise in glucose level stimulates insulin secretion, which lowers plasma glucose, but as a consequence, the sustained hyperinsulinemia inhibits both insulin secretion and action. ${ }^{3}$ Finally, persistent plasma glucose elevation (glukotoxicity) impairs $\beta$-cells function and leads to hepatic and muscle insulin resistance. ${ }^{12} \mathrm{All}$ the patients included in the study had a highly reduced $\beta$-cells function. We also found that majority of the patients had the moderate insulin resistance.

Our results also show that the patients were poorly controlled and obese. It has been found that obesity accompanies $80 \%$ of the diabetics in the Western world. ${ }^{13}$ It is even featured in some subclassifications of diabetes but is not required for diabetes diagnosis. ${ }^{3}$

The weakness of our study is the lack of possibility for comparison of the obtained data with the data at the time of setting the T2DM diagnosis. In spite of that, the published data about initial disfunction show that the progressive decline of $\beta$-cells function exists in a longstanding T2DM patients. It has been found that $50-75 \%$ of the secretory capacity of the $\beta$-cells is already lost by the time fasting hyperglycemia develops. ${ }^{14}$ Once overt T2DM is present, $\beta$-cells function declines progressively with time. ${ }^{2}$ According to United Kingdom Prospective Diabetes Study (UKPDS), the average annual loss of $\beta$-cells function in untreated patients is $4 \% .{ }^{15}$

We have found a variety of combinations of insulin deficiency and insulin resistance in the T2DM patients included in our study. Therefore, estimation of $\beta$-cells function and insulin resistance is important for making the medical decision that will lead to the adequate pharmacological interventions (correction of oral therapy, introduction of basal, combined or intensive insulin therapy ) combined with diet and exercise. This approach may improve and preserve $\beta$-cells function before it reaches critically low levels.

\section{Authorship Statement}

$D K$ is responsible for the study design, the manuscript writing and accuracy of the data analysis, DDS is responsible for the data collection and critical revision of the manuscript, $S H$ participated in the data interpretation and critical revision of the manuscript.

\section{Financial Disclosure}

The authors declare no conflict of interest.

\section{References}

1. Ismail-Beigi F. Pathogenesis and glycemic management of type 2 diabetes mellitus: a physiological approach. Arch Iran Med 2012;15(4):239-46.doi:012154/AIM.o014.

2. DeFronzo RA, Abdul-Ghani MA. Preservation of $\beta$-cell Function: The Key to Diabetes Prevention. I ClinEndocrinolMetab 2011;96(8):2354-66. doi:10.1210/jc.2011-0246.

3. Ferrannini E. Insulin resistance versus insulin deficiency in non-insulin-dependent diabetes mellitus: problems and prospects. Endocr Rev 1998;19(4):477-90.

4. Krentz AJ. Insulin resistance. BMJ 1996;313(7069):1385-9.

5. Kahn BB, Flier JS. Obesity and insulin resistance. JClin Invest 2000;106(4):473-81.

6. Žmire J. Obesity and metabolic insulin resistance. Medicus 2004;13(2):163-71. 
7. Meyer MR, Clegg DJ, Prossnitz ER, et al. Obesity, insulin resistance and diabetes: Sex differences and role of oestrogen receptors. ActaPhysiol(Oxf) 2011;203(1):259-69.doi:10.1111/ j1748-1716.2010.02237.x.

8. Mittelman SD, Van Citters GW, Kim SP, et al. Longitudinal compensation for fat-induced insulin resistance includes reduced insulin clearance and enhanced $\beta$-cell response. Diabetes 2000;49(12):2116-25.

9. Smirčić-Duvnjak L. Pathophysiology of the metabolic syndrome. Medicus 2004;13(2):151-61.

10. Dansuntornwong B, Chanprasertyothin S, Jongjaroenprasert W, et al. The relation between parameters from homeostasis model assessment and glycemic control in type 2 diabetes. J Med Assoc Thai 2007;90(11):2284-90.
11. Wallace TM, Levy JC, Matthews DR. Use and abuse of HOMA modeling. Diabetes Care 2004;27:1487-95.

12. Abdul-GhaniMA.Type 2 Diabetes and the evolving paradigm in glucose regulation. Am J Manag Care 2013;19(3):43-50.

13. BMI Classification.Global Database on Body Mass Index. WHO.2006

14. Kahn SE. The importance of $\beta$-cell failure in the development and progression of type 2 diabetes. J ClinEndocrinolMetab 2001;86(9):4047-58.doi:10.1210/jc.86.9.4047

15. UK Prospective Diabetes Study Group.UK Prospective Diabetes Study 16. Overwiev of 6 years' therapy of type II diabetes: a progressive disease. Diabetes 1995;44:1249-58.

\title{
Funkcija $\beta$-ćelija i inzulinska rezistencija kod dugotrajnog tip 2 diabetes mellitus-a
}

\begin{abstract}
APSTRAKT
Uvod. Svaki pacijent sa tip 2 diabetes mellitus-om secernira manje inzulina nego što je potrebno za njegov/njen nivo inzulinske senzitivnosti, a većina in ima neki stepen inzulinske rezistencije. Mješavina inzulinske deficijencije i inzulinske rezistencije je različita kod svakog pacijenta, a kod bilo kojeg pacijenta može varirati za vrijeme trajanja bolesti. Cilj ove studije je bio da ispita stepen $\beta$-ćelijske funkcije i prisustvo inzulinske rezistencije kod pacijenata sa dugotrajnim tip 2 dijabetesom.
\end{abstract}

Metode. Studija je uključivala 30 pacijenata oba pola (12 muškaraca, 18 žena) sa srednjim vrijednostima starosne dobi 59 godina ( $\mathrm{SD}=7.88)$ i trajanja bolesti 10 godina ( $\mathrm{SD}=5.36)$. Srednja vrijednost $\mathrm{BMl}$ je bila $31 \mathrm{~kg} / \mathrm{m}^{2}(\mathrm{SD}=4.74)$. Koncentracije glukoze i inzulina natašte i HbA1c u krvi su određene korištenjem standardnih laboratorijskih metoda. Procenti funkcionalnih $\beta$-ćelija pankreasa (HOMA-\%B), inzulinske senzitivnosti (HOMA-\%S) i inzulinska rezistencija (HOMA-IR) su izračunati korištenjem HOMA kalkulatora v2.2. Dobiveni podaci su analizirani statističkim softverom SPSS 19.

Rezultati. Srednja vrijednost HbA1c je bila $10 \%$ (SD=1.52), a FBG 12 mmol/L (SD=4.15). Srednja vrijednost insulina je bila 13 umol/L (SD=6.11), a HOMA-\%B 31 \% (SD=18.99). Medijana vrijednosti HOMA-\%S je bila 49 \% (32.2-82.4), a HOMA-IR 2 (1.2-3.1). $87 \%$ pacijenata je imalo HOMA-IR $>1$.

Zaključak. Izrazito snižena $\beta$-ćelijska funkcija i posljedična inzulinska deficijencija, najčešće udružena sa umjerenom inzulinskom rezistencijom je utvrđena kod pacijenata sa dugotrajnim tip 2 diabetes mellitus-om.

\section{KLJUČNE REČI}

Tip 2 dijabetes melitus; funkcija $\beta$-ćelija; rezistentnost na inzulin. 